consequence has been to increase the price of semiconductors in the United States, to the relief of domestic manufacturers, many of whom may prefer the state of affairs thus created to that which would arise if the suits against Japan were decided and found to be invalid. What European manufacturers fear is that, in such circumstances, Japanese manufacturers will be forced into a deal with their counterparts in the United States whose effect will be to increase the price of microchips elsewhere, to the general disbenefit. Cartel is the dirty word that people use to describe this apprehension.

Plainly, it is not at present justifiable for people in Europe to describe the negotiations between US and Japanese manufacturers, or the respective governments, in language of this kind. Nothing like a formal cartel agreement is within sight of negotiation. The more substantial threat to the rest of the world is that Japan and the United States between them control such a large proportion of the world's present production of microchips that the mere conduct of negotiations about price might encourage the manufacturers concerned to slip into understandings about the price of their products that other people would be required to pay through the nose for the benefits thereof. Europeans, and European industries in particular, have good cause to worry on this score, for there have in the past several years been too many occasions on which the commercial interests of the United States have been defended, not always successfully, beneath the umbrella of strategic security. The natural gas pipeline from the Soviet Union to the West is the example that most conspicuously stands out. But the remedy is in European hands. European companies are skilled at designing chips, but are not especially good at manufacturing them in bulk; the threat they perceive from the United States and Japan will be more easily countered if the two concerned should conspire artificially to enhance the prices of their products. Artificially high prices on the international market might even provide the breathing space in which a European industry might gather its strength and resources. In short, there is no case for defensive paranoia.

Even so. Europe does have a just but lesser cause for complaint. The negotiations between the United States and Japan on trade have been conducted (as is inevitable) between the world's economic superpowers in virtual indifference to how the rest of the world may be affected by their mutual relationships. Both to the United States and Japan, Europe has become a consumer market and one that seems to be in an old-fashioned way unreasonably protectionist, of its agriculture in particular. Here again, the remedy is in Europe's hands, but will not be easily attained. Putting real flesh and blood on the skeleton of the common market promised by the Treaty of Rome lies still a long way off. Ironically, the most common misunderstanding between the United States and Europe is that the former behaves as if the former were a reality already, which alone can explain why Washington expects Europe to be capable of a single reaction on matters such as, say, Libya, while Europe still relishes its interesting but sapping diversity.

\section{More apartheid ironies}

A conference at Berkeley puts recent events in Southampton in context.

THE: decision by the organizers of the World Archaeological Congress to be held in Southampton, England, in September to exclude participants from South Africa and Namibia has sharply divided the community of archaeologists, but needlessly. A conference being held this week at Berkeley, California, seems to show that when rhetoric and bombast are kept to a minimum, academic discussion can be conducted without rancour. The five-day conference at Berkeley under the title "The longest record: the human career in Africa", was organized by Jack Harris of the University of Wisconsin and the late G. LI. Isaac of Harvard University to honour Professor J. Desmond Clark, retiring this year from the University of California. Professor Clark has left an indelible mark on the study of African prehistory since the beginning of his professional life in the 1930s. He is respected not only for his academic contributions, but also for his diplomatic skill in maintaining research projects despite political obstacles in Africa.

The Berkeley conference seems destined to achieve precisely the goal of true international participation that prompted the organizers at Southampton to exclude South African researchers. The expectation that representatives from black African nations would boycott a conference attended by South Africans has failed to materialize at Berkeley. A mailing sent to all pre-registrants for the conference clearly listed participants from South Africa, Kenya, Malawi, Nigeria, Sudan, Tanzania and Zambia, as well as the United States, Canada and Europe. Not only has a boycott failed to materialize, the ranks of the conference have been swollen; 240 registrants paid the modest $\$ 25$ fee to attend. Formal sessions at the conference were scheduled to start at $8 \mathrm{a} . \mathrm{m}$. and continue until $10 \mathrm{p} . \mathrm{m}$. to accommodate the 160 papers submitted. Why such worldwide enthusiasm? Clearly Professor Clark has captured tremendous respect and affection from the people with whom he has worked. The efforts of organizers Isaac (before his untimely death last September) and Harris to include all aspects of early human activity in Africa have had an effect. By including a oneday symposium on rock art, Harris was able to coax a $\$ 10,000$ grant out of the financially strapped National Endowment for the Humanities. It is also the case that there has not been a good conference on early hominids in Africa since the Pan African Congress in 1977 in Kenya. There may also be other explanations of this enthusiasm, but it would seem that the conference has shown that a large segment of the prehistory community regards academic meetings as the wrong forum for making political statements.

The Berkeley conference has also shown what should in any case have been apparent, that successful meetings can take place even among communities sensitized to political issues. It can hardly be argued that students at Berkeley are significantly less interested in abolishing apartheid in South Africa than their counterparts in Southampton. Early this month, 87 students were arrested on the University of California campus in violent clashes with police over "shantytowns" erected on campus to call attention to the plight of South African blacks. There has been no disruption of the anthropology meeting. Not that the organizers were unaware that disruptions were possible. They merely chose not to call attention to their activities. Since the meeting coincides with the spring break on the Berkeley campus, student protests may have been blunted by hedonism, on which Southampton could also have counted. The issue of South African participation in international conferences should be an issue decided by individuals, not scientific bodies. It is one thing for a government, presumably acting on behalf of its people, to decide to isolate one country from the rest of the world community. But professionally competent though they may be, anthropologists and archaeologists should not be setting political agendas for international relations. If the moral issue of excluding South African scientists from scientific meetings were as clear-cut as the organizers at Southampton seem to believe, there would be no issue at all. Since the International Union of Prehistoric and Protohistoric Sciences (IUPPS) withdrew its support from the Southampton Congress, it has been clear that matters are not that cut and dried. One of life's little ironies of which the Southampton organizers will now be aware is that one of the participants at the Berkeley meeting is now also a member of the Southampton organizing committee. Another is that Harris suggested that Peter Ucko, Southampton organizing secretary, be a reviewer of the grant application to the National Endowment for the Humanities; the grant was used in part to pay travel expenses of South African participants. One wonders what Ucko's comments would have been. 